\title{
PENGARUH KEDISIPLINAN DAN INSENTIF TERHADAP KINERJA KARYAWAN PADA PT. PNM (PERMODALAN NASIONAL MADANI) ULaMM CABANG PADANGSIDIMPUAN
}

\author{
Muhammad Isa \\ Institut Agama Islam Negeri Padangsidimpuan \\ Jalan T. Rizal Nurdin Km. 4,5 Sihitang, Padangsidimpuan \\ Email: misastmm@gmail.com
}

\begin{abstract}
Abstrak,
Penelitian ini dilatarbelakangi oleh kinerja karyawan PT. PNM (Permodalan Nasional Madani) ULaMM Padangsidimpuan yang belum maksimal sesuai yang diharapkan. Tujuan penelitian ini adalah untuk mengetahui pengaruh kedisiplinan dan insentif terhadap kinerja karyawan PT. PNM (Permodalan Nasional Madani) ULaMM Padangsidimpuan. Penelitian ini dilaksanakan secara kuantitatif menggunakan instrumen kuesioner yang disebarkan kepada 45 orang responden. Pengolahan data dilakukan dengan teknik regresi linier berganda dibantu dengan softwere SPSS versi 22. Hasil dari penelitian ini adalah: kedisiplinan secara parsial tidak berpengaruh terhadap kinerja karyawan PT. PNM (Permodalan Nasional Madani) ULaMM Padangsidimpuan, sedangkan insentif secara parsial berpengaruh terhadap kinerja karyawan PT. PNM (Permodalan Nasional Madani) ULaMM Padangsidimpuan. Selanjutnya secara simultan kedisiplinan dan insentif secara simultan berpengaruh terhadap kinerja karyawan PT. PNM (Permodalan Nasional Madani) ULaMM Padangsidimpuan.
\end{abstract}

Kata Kunci: Kedisiplinan, Insentif, Kinerja Karyawan

\begin{abstract}
,
This research is important because employees performance in PT. PNM (Permodalan Nasional Madani) ULaMM Padangsidimpuan are low. The aims of this research are to know the effects of discipline and incentive to employee performance in PT. PNM (Permodalan Nasional Madani) ULaMM Padangsidimpuan. This is a quantitative research. The data collected by using questionnaires with 45 persons. The data analyzed by using correlation and regression through SPSS versi 22. The results of this research are: discipline has no significant partial effect to employee performance, incentive has significant partial effect to employee performance. Then discipline and incentive have significant simultan effect to employee performance in PT. PNM (Permodalan Nasional Madani) ULaMM Padangsidimpuan.
\end{abstract}

Key words: Discipline, Incentive, Employee performance

\section{PENDAHULUAN}

Manajemen Sumber Daya Manusia (SDM) merupakan konsep luas tentang filosofi, kebijakan, prosedur, dan taktik yang digunakan untuk mengelola individu atau manusia melalui organisasi. Penggunaan konsep dan sistem sumber daya manusia adalah kontrol secara sistematis dari proses jaringan fundamental organisasi yang memengaruhi dan melibatkan semua individu dalam organisasi, termasuk proses perencanaan sumber daya manusia, desain pekerjaan, susunan kepegawaian, pelatihan, dan pengembangan, representasi dan perlindungan tenaga kerja serta pengembangan organisasi.

Sumber daya manusia adalah faktor sentral dalam satu organisasi. Apapun bentuk serta tujuannya, organisasi dibuat berdasarkan berbagai misi untuk kepentingan manusia dan 
dalam pelaksanaannya misi tersebut dikelola oleh manusia. Jadi manusia merupakan faktor strategis dalam semua kegiatan organisasi. Oleh karena itu kualitas sumber daya manusia senantiasa harus ditingkatkan dan diarahkan agar bisa mencapai tujuan perusahaan. Karyawan dalam sebuah perusahaan diharapkan mampu memberikan kinerja terbaiknya untuk kemajuan perusahaan. Peningkatan kinerja ini dapat ditempuh dengan berbagai cara antara lain dengan meningkatkan kedisiplinan dan pemberian insentif.

PT. PNM (Permodalan Nasional Madani) ULaMM Padangsidimpuan merupakan salah satu perusahaan lembaga keuangan yang berstatus Badan Usaha Milik Negara (BUMN). Manajemen perusahaan ini tentunya berusaha untuk meningkatkan kinerjanya dari waktu ke waktu. Perusahaan ini juga mengutamakan kedisiplinan karyawan, dan pemberian insentif dalam upayanya untuk meningkatkan kinerja karyawan yang pada akhirnya akan meningkatkan kinerja perusahaan.

Dalam usaha meningkatkan kedisiplinan karyawan maka pihak manajemen perusahaan telah menyusun peraturan-peraturan, sistem dan prosedur pekerjaan dan petunjuk pelaksanaan (juklak) pekerjaan serta telah disosialisasikan kepada seluruh karyawan. Peraturan-peraturan yang telah dibuat ini diharapkan dapat dipatuhi dan dipedomani karyawan dalam bekerja. Karyawan yang disiplin, yaitu karyawan yang bekerja sesuai dan mematuhi aturan yang dibuat, akan mampu bekerja dengan baik dan berkinerja maksimal untuk kemajuan perusahaan. Melihat ketatnya persaingan dunia usaha sekarang maka setiap perusahaan, termasuk PT. PNM (Permodalan Nasional Madani) ULaMM Padangsidimpuan, membutuhkan karyawan dengan kedisiplinan yang baik untuk mencapai kinerja yang baik.

Penerapan disiplin kerja di lingkungan kerja, memang pada awalnya akan dirasakan berat oleh para karyawan, tetapi apabila terus menerus diberlakukan akan menjadi kebiasaan, dan disiplin tidak akan menjadi beban berat bagi para karyawan apalagi jika ditambah dengan insentif yang akan diterima karyawan dari perusahaan. Disiplin perlu diterapkan, karena disiplin tidak lahir begitu saja, tetapi perlu adanya pembinaan-pembinaan dalam menegakkan disiplin kerja.

Di sisi lain, insentif yang diterima karyawan dari perusahaan juga akan berdampak pada meningkatnya kinerja karyawan dalam perusahaan. Pemberiaan insentif akan mendorong karyawan untuk bekerja secara profesional untuk mencapai tujuan, serta visi dan misi dalam perusahaan. Berikut ini besaran insentif yang diterima karyawan PT. PNM (Permodalan Nasional Madani) UlaMM Padangsidimpuan dalam beberapa tahun terakhir.

Tabel 1. Insentif Karyawan Pada PT. PNM ULaMM Padangsidimpuan

\begin{tabular}{|l|l|l|l|}
\hline \multirow{2}{*}{ Tahun } & \multirow{2}{*}{ Rata-Rata Insentif } & Kategori & \multirow{2}{*}{ Keterangan } \\
\hline \multirow{2}{*}{2013} & \multirow{2}{*}{ Rp. $200.000-400.000$} & Karyawan Proaktif & \multirow{2}{*}{ Per 1 bulan } \\
\cline { 2 - 3 } & Rp. $50.000-100.000$ & Karyawan Aktif & \multirow{2}{*}{ Per 2 bulan } \\
\cline { 3 - 3 } & & Karyawan & Karyawan Baru \\
\hline
\end{tabular}




\begin{tabular}{|c|c|c|c|}
\hline \multirow{4}{*}{2014} & \multirow{2}{*}{ Rp. $200.000-500.000$} & Karyawan Proaktif & \multirow{2}{*}{ Per 1 bulan } \\
\hline & & Karyawan Aktif & \\
\hline & \multirow{2}{*}{ Rp. $50.000-200.000$} & Karyawan & \multirow{2}{*}{ Per 2 bulan } \\
\hline & & Karyawan Baru & \\
\hline \multirow{4}{*}{2015} & \multirow{2}{*}{ Rp. $200.000-600.000$} & Karyawan Proaktif & \multirow{2}{*}{ Per 1 bulan } \\
\hline & & Karyawan Aktif & \\
\hline & \multirow{2}{*}{ Rp. $50.000-300.000$} & Karyawan & \multirow{2}{*}{ Per 2 bulan } \\
\hline & & Karyawan Baru & \\
\hline \multirow{4}{*}{2016} & \multirow{2}{*}{ Rp. $200.000-800.000$} & Karyawan Proaktif & \multirow{2}{*}{ Per 1 bulan } \\
\hline & & Karyawan Aktif & \\
\hline & \multirow{2}{*}{ Rp. $50.000-500.000$} & Karyawan & \multirow{2}{*}{ Per 2 bulan } \\
\hline & & Karyawan Baru & \\
\hline
\end{tabular}

Sumber : Juklak Aktivitas Operasional Keuangan ULaMM.

Dari tabel di atas terlihat bahwa insentif yang diterima karyawan tiap tahunnya mengalami peningkatan sesuai dengan kategori karyawan dalam perusahaan. Berdasarkan hasil wawancara dengan Bapak ESZ selaku Marketing Unit dalam perusahaan ini, ia mengatakan bahwa usaha penegakan disiplin karyawan dan pemberian insentif ini bertujuan untuk meningkatkan kinerja karyawan.

Bapak ESZ mengungkapkan bahwa mereka terus berusaha memacu kinerja perusahaan yang dipimpinnya, namun ia mengatakan bahwa pencapaian kinerja berupa laba yang mereka peroleh masih di bawah target yang telah ditetapkan. Bapak ESZ mengatakan secara umum kinerja perusahaan PT. PNM UlaMM Padangsidimpuan relatif tetap atau tidak mengalami peningkatan yang berarti walaupun dengan adanya program peningkatan disiplin dan pemberian insentif bagi karyawan. Hal inilah salah satu hal yang mendorong dilakukannya penelitian ini. Berdasarkan latar belakang tersebut maka dilakukan penelitian yang berjudul "Pengaruh Kedisiplinan Dan Insentif Terhadap Kinerja Karyawan Pada PT. PNM (Permodalan Nasional Madani) ULaMM Padangsidimpuan”.

Adapun tujuan penelitian ini adalah:

1. Untuk mengetahui pengaruh kedisiplinan secara parsial terhadap kinerja karyawan pada PT. PNM (Permodalan Nasional Madani) ULaMM Padangsidimpuan.

2. Untuk mengetahui pengaruh insentif secara parsial terhadap kinerja karyawan pada PT. PNM (Permodalan Nasional Madani) ULaMM Padangsidimpuan.

3. Untuk mengetahui pengaruh kedisplinan dan insentif secara simultan terhadap kineja karyawan di PT. PNM (Permodalan Nasional Madani) ULaMM Padangsidimpuan.

\section{TINJAUAN TEORITIK}

\section{KEDISIPLINAN}

Menurut Veithzal Rivai (Rivai, 2004) disiplin kerja adalah suatu alat yang digunakan para menejer untuk berkomunikasi dengan karyawan agar mereka bersedia untuk mengubah suatu perilaku serta sebagai suatu upaya untuk meningkatkan kesadaran dan kesediaan seseorang untuk menaati semua peraturan perusahaan dan norma-norma sosial yang berlaku. 
Sedangkan menurut Malayu S.P Hasibuan (Hasibuan, 2002) kedisiplinan adalah kesadaran dan kesediaan seseorang menaati semua peraturan dan norma yang berlaku. Kesadaran adalah sikap seseorang yang sukarela menaati semua peraturan dan sadar akan semua tanggung jawabnya. Dimana kesediaan adalah suatu sikap, tingkah laku dan perbuatan seseorang yang sesuai dengan peraturan, baik tertulis maupun tidak tertulis.

Oleh karena itu dapat disimpulkan bahwa disiplin kerja adalah perilaku seseorang yang sesuai dengan peraturan yang telah ditetapkan oleh sebuah organisasi baik secara tertulis maupun tidak tertulis, atau kemauan dan kemampuan seseorang menyesuaikan kondisi internalnya dan mengendalikan dirinya agar sesuai dengan norma, aturan, hukum, dan kebiasaan yang berlaku.

Dalam ajaran Islam dijelaskan kedisiplinan kerja dalam arti ketaatan dalam bekerja adalah suatu kewajiban yang harus dipenuhi dan tidak boleh melanggar peraturan-peraturan yang telah ditetapkan. Sebagaimana diterangkan dalam firman Allah SWT dalam Q.S An-Nisa' :59.

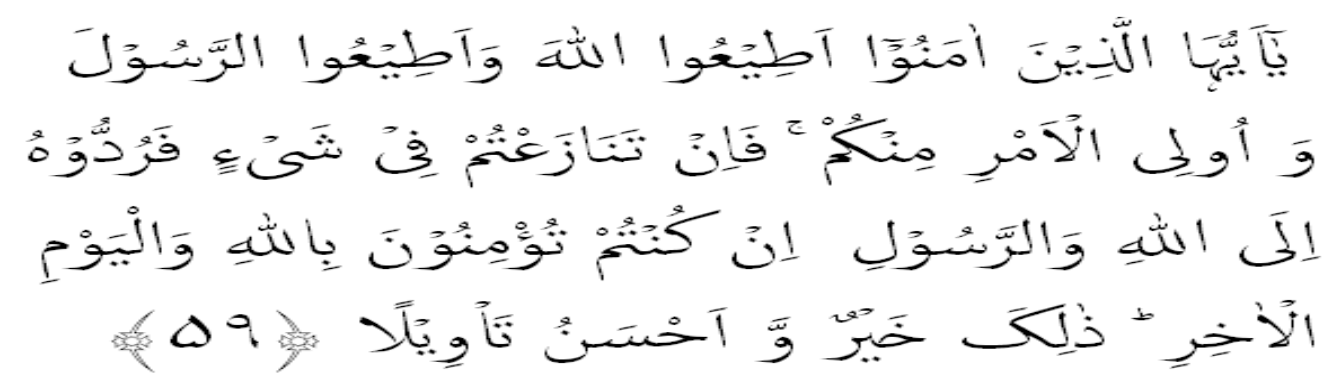

Artinya : "Hai orang-orang beriman, taatilah Allah dan taatilah rasul (Nya), dan Ulil Amri di antara kamu. Kemudian jika kamu berlainan pendapat tentang sesuatu, maka kembalikanlah ia kepada Allah (Al-Qur'an) dan Rasul (Sunnahnya), jika kamu benar-benar beriman kepada Allah dan hari kemudian yang demikian itu lebih utama (bagimu) dan lebih baik akibatnya”. (Q.S An-Nisa' : 59).

Kedisiplinan sangat diperlukan untuk menunjang kelancaran segala aktivitas organisasi agar tujuan organisasi dapat dicapai secara maksimal. Untuk itu seorang manajer perusahaan perlu memperhatikan sikap disiplin karyawannya. Bentuk disiplin yang baik akan tercermin pada suasana yaitu: tingginya rasa kepedulian karyawan terhadap pencapaian tujuan perusahaan; tingginya gairah dan semangat kerja dan inisiatif para karyawan dalam melakukan pekerjaan; besarnya rasa tanggung jawab para karyawan untuk melaksanakan tugas dengan sebaik-baiknya; berkembangnya rasa memiliki dan rasa solidaritas yang tinggi dikalangan karyawan; meningkatnya efisiensi dan produktivitas kerja para karyawan.

Keteraturan adalah ciri utama organisasi dan disiplin adalah salah satu metode untuk memelihara keteraturan. Tujuan utama disiplin adalah untuk meningkatkan efisiensi semaksimal mungkin dengan cara mencegah pemborosan waktu dan energi. Selain itu, disiplin mencoba untuk mencegah kerusakan atau kehilangan harta benda, mesin, peralatan 
dan perlengkapan kerja yang disebabkan oleh ketidakhati-hatian, senda gurau, atau pencurian.

Secara tidak langsung, disiplin mencoba mengatasi kesalahan dan keteledoran yang disebabkan karena kurang perhatian, ketidak mampuan, dan keterlambatan. Disiplin berusaha mencegah permulaan kerja yang lambat atau terlalu awalnya mengakhiri kerja yang disebabkan karena keterlambatan atau kemalasan. Disiplin juga berusaha untuk mengatasi perbedaan pendapat antar karyawan dan mencegah ketidaktaatan yang disebabkan oleh salah pengertian dan salah penafsiran (Dessler, 2007).

Ada beberapa macam tipe-tipe kedisiplinan dalam organisasi yaitu:

\section{Disiplin Preventif}

Disiplin preventif kegiatan yang dilaksanakan untuk mendorong para karyawan agar mengikuti berbagai standar dan aturan. Sasaran pokoknya adalah untuk mendorong disiplin diri diantara para karyawan menjaga disiplin diri mereka bukan semata-mata dipaksa manajemen. Keberhasilan penerapan pendisiplinan preventif terletak pada disiplin pribadi anggota organisasi.

\section{Disiplin Korektif}

Displin Korektif adalah kegiatan yang diambil untuk menangani pelanggaran terhadap aturan-aturan dan mencoba untuk menghindari pelanggaran-pelanggaran lebih lanjut. Kegiatan korektif sering berupa suatu bentuk hukuman dan disebut tindakan pendisiplinan (disciplinary action).

\section{Disiplin Progresif}

Disiplin progresif berarti memberikan hukuman-hukuman yang lebih berat terhadap pelanggaran-pelanggaran berulang. Tujuannya memberikan kesempatan kepada karyawan untuk mengambil tindakan korektif sebelum hukuman yang lebih serius dilaksanakan. Disiplin progresif memungkinkan manajemen untuk membantu karyawan memperbaiki kesalahan.

\section{Indikator-indikator Kedisiplinan}

Menurut Malayu Hasibuan Indikator-indikator tingkat kedisplinan karyawan, diantarnya adalah : 1) tujuan dan kemampuan, artinya tujuan atau pekerjaan yang dibebankan kepada karyawan harus sesuai dengan kemampuan karyawan yang bersangkutan, agar bekerja sungguh-sungguh dan disiplin dalam mengerjakannya; 2) teladan pimpinan, artinya dengan teladan pimpinan yang baik, kedisiplinan bawahan pun ikut baik. Jika teladan pimpinan kurang baik, para bawahan pun akan kurang disiplin; 3) balas jasa, artinya balas jasa akan memberikan kepuasan dan kecintaan karyawan terhadap perusahaan. Jika kecintaan karyawan semakin baik terhadap pekerjaan, kedisiplinan mereka akan semakin baik pula; 4) ketegasan, artinya pimpinan yang berani bertindak tegas menerapkan hukuman bagi 
karyawan yang indisipliner akan disegani dan diakui kepemimpinannya oleh bawahan; 5) hubungan kemanusiaan, artinya kedisiplinan karyawan akan tercipta apabila hubungan kemanusiaan dalam organisasi tersebut baik (Hasibuan, 2002).

\section{INSENTIF}

Insentif merupakan setiap sistem kompensasi dimana jumlah yang diberikan tergantung pada hasil yang dicapai, yang berarti menawarkan sesuatu insentif kepada pekerja untuk mencapai hasil yang lebih baik (Harsono, 1987). Insentif merupakan sistem formal dalam pemberian ganjaran dengan menetapkan besarnya bonus dalam bentuk uang. Dengan demikian berarti besarnya bonus tergantung pada kemampuan para karyawan mereduksi pembiayaan yang dapat terjadi jika pekerja mampu meningkatkan produktivitas kerja (Nawawi, 2011).

Keberhasilan suatu perusahaan dalam mencapai tujuan yang telah ditetapkan bergantung pada orang-orang yang berada dalam lingkungan perusahaan. Salah satu cara yang dapat ditempuh oleh perusahaan dalam mencapai tujuannya adalah dengan meningkatkan kualitas kerja serta tingkah laku yang baik dalam bekerja. Pemberian insentif merupakan salah satu cara perusahaan untuk meningkatkan kualitas kerja personil atau karyawan. Pemberian insentif oleh perusahaan merupakan upaya untuk memenuhi kebutuhan karyawan, jika perusahaan memperhatikan dan memenuhi kebutuhan para karyawannya, baik kebutuhan yang bersifat materi maupun kebutuhan yang bersifat non materi (Suwanto, 2013).

Menurut Gorda (Suwanto,2013) pemberian insentif atau upah bertujuan : 1) memberikan balas jasa yang berbeda dikarenakan hasil kerja yang berbeda, 2) mendorong semangat kerja karyawan dan memberikan kepuasan, 3) meningkatkan produktivitas, 4) pemberian insentif dimaksudkan untuk menambah penghasilan karyawan sehingga dapat memenuhi kebutuhannya.

\section{Macam-macam Insentif}

Adapun macam insentif yang di berikan dalam suatu perusahaan kepada karyawan adalah sebagai berikut : 1) insentif material, yaitu daya perangsang yang diberikan kepada karyawan berdasarkan prestasi kerjanya, berbentuk uang atau barang. Insentif material bernilai ekonomis sehingga dapat meningkatkan kesejahteraan karyawan; 2) insentif non material, merupakan daya perangsang yang diberikan kepada karyawan yang berbentuk penghargaan, promosi, tanda jasa, medali, atau pengukuhan berdasarkan prestasi kerjanya. Pemberian ujian lisan atau tulis

\section{Prinsip Pemberian Insentif}

Pada dasarnya pemberian insentif senantiasa dihubungkan dengan balas jasa atas prestasi ekstra yang melebihi suatu standar yang telah ditetapkan serta telah disetujui bersama. Pengaturan insentif harus ditetapkan dengan cermat dan tepat serta harus dikaitkan 
secara erat dengan tujuan-tujuan perusahaan yang bersangkutan. Jumlah insentif yang diberikan kepada seseorang harus dihubungkan dengan jumlah atau apa yang telah dicapai selama periode tertentu, sesuai dengan rumus pembagian yang telah diketahui semua pihak secara nyata.

Bagi Perusahaan, insentif bertujuan mempertahankan tenaga kerja yang terampil agar loyalitasnya tinggi terhadap perusahaan, mempertahankan dan meningkatkan moral kerja pegawai yang ditunjukkan akan menurunnya tingkat perputaran tenaga kerja dan absensi, meningkatkan produktivitas perusahaan yang berarti hasil produksi bertambah untuk setiap unit persatuan waktu dan penjualan yang meningkat.

Sedangkan bagi karyawan insentif bertujuan meningkatkan standar kehidupannya dengan diterimanya pembayaran di luar gaji pokok, meningkatkan semangat kerja pegawai sehingga mendorong mereka untuk berprestasi lebih baik. Setiap orang apabila ditawarkan suatu ganjaran yang memberikan hasil yang cukup menguntungkan maka seseorang itu akan termotivasi untuk memperolehnya. Alat motivasi yang kuat itu adalah dengan memberikan insentif.

\section{Indikator-indikator Insentif}

Beberapa Indikator-indikator yang menjadi pertimbangan cara penyusunan insentif adalah : 1) kinerja, sistem insentif dengan cara ini langsung mengkaitkan besarnya insentif dengan kinerja yang telah ditunjukkan oleh pegawai yang bersangkutan; 2) lama kerja, dimana besarnya insentif ditentukan atas dasar lamanya pegawai menyelesaikan suatu pekerjaan; 3) senioritas, dimana sistem insentif ini didasarkan pada masa kerja atau senioritas karyawan yang bersangkutan dalam suatu organisasi; 4) kebutuhan, insentif dengan cara ini menunjukkan bahwa insentif pada pegawai didasarkan pada tingkat urgensi kebutuhan hidup yang layak dari pegawai; 5) keadilan dan kelayakan, yaitu makin tinggi pengorbanan karyawan maka semakin tinggi insentif yang diharapkan, oleh karenanya yang harus dinilai adalah pengorbanannya yang diperlukan dalam suatu jabatan; 6) evaluasi jabatan, yaitu suatu usaha untuk menentukan dan membandingkan nilai suatu jabatan tertentu dengan nilai jabatanjabatan lain dalam suatu organisasi. Ini berarti penentuan nilai relatif atau harga dari suatu jabatan guna menyusun rangking dalam penentuan insentif (Suwanto, 2013).

\section{KINERJA}

Kinerja merupakan gambaran mengenai tingkat pencapaian pelaksanaan suatu kegiatan, program, kebijakan dalam mewujudkan sasaran, tujuan, misi dan visi yang tertuang dalam perencanaan strategi organisasi (Fahmi, 2012). Sedangkan dalam Kamus Besar Bahasa Indonesia kinerja adalah sesuatu yang dicapai, prestasi yang diperlihatkan atau kemampuan kerja (Departemen Pendidikan Nasional, 2005). 
Berdasarkan uraian di atas dapat disimpulkan bahwa kinerja merupakan hasil dari pekerjaan yang dilakukan oleh seseorang dalam sebuah perusahaan atau organisasi sesuai dengan yang diharapkan oleh perusahaan dan sekaligus untuk mencapai tujuan organisasi tersebut. Adapun kinerja merupakan hasil kerja secara kualitas dan kuantitas yang dapat dicapai oleh para karyawan dalam melaksanakan tugas sesuai dengan tanggung jawab yang diberikan kepadanya.

Sedangkan dalam pandangan Islam, Islam adalah agama yang mengutamakan kerja. Bahwa kesempurnaan iman seseorang antara lain adalah karena kerja, dengan kata lain setiap Muslim wajib bekerja atau beramal. Seperti dalam Al-Qur'an surat An-Nisa' : 32.

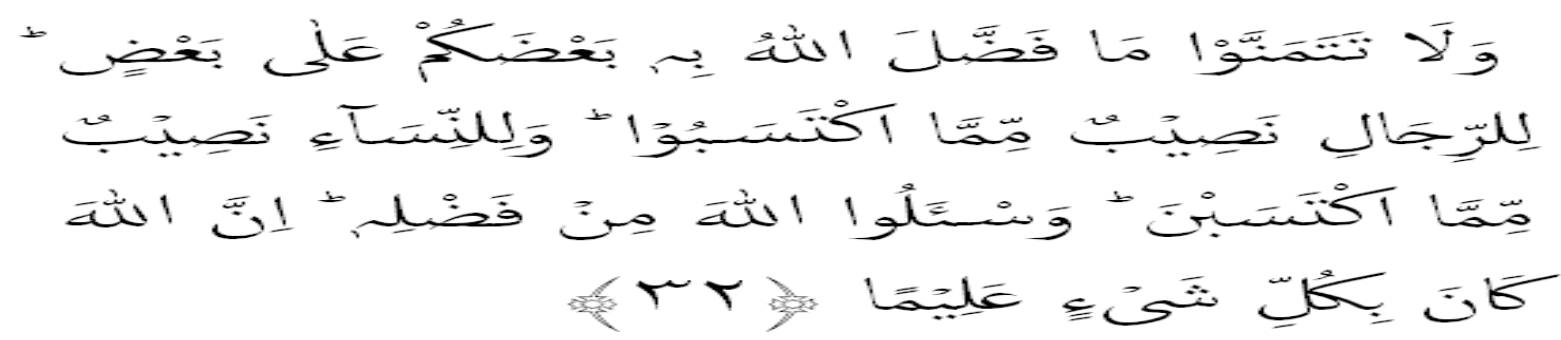

Artinya : "Dan janganlah kamu iri hati terhadap apa yang dikaruniakan Allah kepada sebahagian kamu lebih banyak dari sebahagian yang lain. (karena) bagi orang lakilaki ada bahagian dari pada apa yang mereka usahakan, dan bagi para wanita (pun) ada bahagian dari apa yang mereka usahakan, dan mohonlah kepada Allah sebagian dari karunia-Nya. Sesungguhnya Allah Maha mengetahui segala sesuatu. (Q.S An-Nisa" : 32).

Dalam ayat di atas Allah SWT tidak membedakan laki-laki dan perempuan, salah satunya termasuk dalam pekerjaan sebab kerja adalah ibadah. Hal ini menunjukkan bahwa setiap kinerja seseorang dalam sebuah perusahaan semata-mata diberikan bukan hanya untuk memenuhi kebutuhan duniawi, melainkan untuk mendekatkan diri kepada Allah SWT. Oleh karena itu dimulai dengan adanya niat yang baik, pekerjaan apapun dilakukan secara ikhlas, disertai berdo'a dan berusaha.

\section{Tujuan dan Manajemen Kinerja}

Tujuan manajemen kinerja adalah untuk mewujudkan tujuan suatu perusahaan. Agar bisa menerapkan konsep manajemen kinerja yang berkualitas dan profesional maka perlu memahami apa yang menjadi tujuan menyeluruh dan spesifik dari manajemen kinerja. Dalam hal ini Michael Armstrong mengatakan "Tujuan menyeluruh manajemen kinerja adalah untuk menumbuhkan suatu budaya dimana individu dan kelompok bertanggung jawab atas kelanjutan peningkatan proses bisnis dan peningkatan keterampilan dan kontribusi mereka sendiri". Artinya peningkatan manajemen kinerja bukan hanya berpengaruh pada peningkatan hasil di perusahaan saja, namun lebih jauh dari itu yaitu mampu menjadi nilai tambah bagi para karyawan. Seorang karyawan pada saat diterapkannya manajemen kinerja maka kemampuan dan kualitas dalam bekerja juga menjadi lebih baik, karena ia terbiasa bekerja sesuai dengan konsep tujuan dan elemen manajemen kinerja (Handoko, 1988). 
Manajemen kinerja akan dapat diwujudkan jika ada hubungan dan keinginan yang sinergi antara atasan dan bawahan dalam usaha mewujudkan visi dan misi perusahaan. Untuk itu salah satu dasar mewujudkan konsep manajemen kinerja adalah dengan mengembangkan dan mengedepankan komunikasi yang efektif antar berbagai pihak baik di lingkungan internal perusahaan dan eksternal perusahaan.

Chaizi Nasucha mengemukakan bahwa kinerja organisasi adalah sebagai efektivitas organisasi secara menyeluruh untuk memenuhi kebutuhan yang ditetapkan dari setiap kelompok yang berkenaan dengan usaha-usaha yang sistemik dan meningkatkan kemampuan organisasi secara terus menerus mencapai kebutuhannya secara efektif.

\section{Indikator-indikator Kinerja}

Adapun Indikator-indikator penyusun kinerja, yaitu: 1) kualitas kerja, yaitu hasil pekerjaan yang sesuai dengan standar yang telah ditetapkan; 2) ketepatan waktu, yaitu berkaitan dengan sesuai atau tidaknya waktu penyelesaian pekerjaan dengan target waktu yang direncanakan; 3) inisiatif, yaitu kesadaran diri untuk melakukan sesuatu dalam melaksanakan tugas-tugas dan tanggung jawab; 4) kemampuan, yaitu kemampuan menuntaskan pekerjaan yang diberikan yang dapat di intervensi atau diterapi melalui pendidikan dan latihan; 5) komunikasi, yaitu interaksi yang dilakukan oleh atasan kepada bawahan untuk mengemukakan saran dan pendapatnya dalam memecahkan masalah yang dihadapi.

\section{METODE PENELITIAN}

Penelitian ini dilakukan di PT. PNM (Permodalan Nasional Madani) ULaMM Padangsidimpuan yang beralamat di Jalan Sisingamangaraja Kelurahan Sitamiang Padangsidimpuan.Jenis penelitian yang digunakan adalah penelitian kuantitatif. Penelitian kuantitatif didefenisikan sebagai penelitian ilmiah yang sistematis dan terhadap bagian dari fenomena serta hubungan-hubungannya (Margono, 2004).

Populasi penelitian ini adalah seluruh karyawan pada PT. PNM (Permodalan Nasional Madani) ULaMM Padangsidimpuan yaitu sebanyak 45 orang. Mengingat populasi penelitian yang sedikit, maka merujuk pada pendapat Suharsimi Arikunto: Sampel adalah ancer-ancer “apabila subjeknya kurang dari 100 orang sebaiknya diambil semua, sehingga penelitiannya merupakan penelitian populasi (Arikunto, 1999). Oleh karena itu dalam penelitian ini digunakan sampel sebanyak 45 orang yakni karyawan keseluruhan dalam PT. PNM (Permodalan Nasional Madani) ULaMM Padangsidimpuan.

Penelitian ini secara umum terdiri dari dua variabel bebas yaitu kedisiplinan dan insentif serta satu variabel terikat yaitu kinerja karyawan. Untuk mengukur ketiga variabel tersebut digunakan kuesioner dengan kisi-kisi instrumen sebagai berikut:

\section{Tabel 2}




\begin{tabular}{|c|c|}
\hline Variabel & Indikator \\
\hline $\begin{array}{l}\text { Kedisiplinan } \\
\left(\mathrm{X}_{1}\right)\end{array}$ & $\begin{array}{l}\text { 1. Tujuan dan } \\
\text { Kemampuan } \\
\text { 2. Teladan Pimpinan } \\
\text { 3. Balas Jasa } \\
\text { 4. Hubungan } \\
\text { Kemanusiaan } \\
\text { 5. Ketegasan }\end{array}$ \\
\hline $\begin{array}{c}\text { Insentif } \\
\left(\mathrm{X}_{2}\right)\end{array}$ & $\begin{array}{l}\text { 1. Kinerja } \\
\text { 2. Lama kerja } \\
\text { 3. Senioritas } \\
\text { 4. Kebutuhan } \\
\text { 5. Keadilan dan kelayakan } \\
\text { 6. Evaluasi jabatan }\end{array}$ \\
\hline $\begin{array}{l}\text { Kinerja } \\
\text { Karyawan } \\
\text { (Y) }\end{array}$ & $\begin{array}{l}\text { 1. Kualitas Kerja } \\
\text { 2. Ketepatan Waktu } \\
\text { 3. Inisiatif } \\
\text { 4. Kemampuan } \\
\text { 5. Komunikasi }\end{array}$ \\
\hline
\end{tabular}

Berdasarkan permasalahan pada penelitian dan metode yang digunakan, maka digunakan instrumen kuesioner dengan skala Likert. Sebelumnya dilakukan uji coba instrumen untuk memastikan bahwa instrumen yang digunakan benar-benar andal untuk mengukur apa yang akan diukur. Dalam hal ini digunakan uji validitas dan uji reliabilitas. Dari seluruh item kuesioner yang diujicoba semuanya valid. Selanjutnya dari uji reliabilitas diperoleh nilai Cronbach Alpha untuk semua variabel > o,6. Jika nilai Cronbach Alpha > 0,6 maka pertanyaan-pertanyaan yang digunakan untuk mengukur variabel tersebut adalah "Reliabel" (Priyanto, 2012). Oleh karena itu item-item kuesioner yang digunakan dalam penelitian ini semuanya reliabel.

Selanjutnya dilakukan pengolahan data dengan rumus regresi linear berganda yang diawali dengan uji asumsi klasik. Uji Asumsi Klasik terdiri dari: 1) uji normalitas untuk melihat apakah nilai residual terdistribusi normal atau tidak; 2) uji linearitas yaitu suatu upaya untuk memenuhi salah satu asumsi analisis regresi linear yang mensyaratkan adanya hubungan variabel bebas dan variabel terikat; 3) uji multikolinearitas yang bertujuan untuk melihat ada atau tidaknya korelasi (keterkaitan) yang tinggi antara variabel-variabel bebas dalam suatu model regresi linear berganda (Sugiono dan Susanto, 2015); 4) uji heteroskedastisitas, yaitu untuk melihat apakah terdapat ketidaksamaan varians dari residual satu ke pengamatan yang lain.

Langkah berikutnya adalah perhitungan koefisien korelasi (R) dan uji koefisien determinasi $\left(\mathrm{R}^{2}\right)$ untuk mengukur besarnya kontribusi $\mathrm{X}_{1}$ (Kedisiplinan) dan $\mathrm{X}_{2}$ (Insentif) terhadap variasi (naik turunnya) Y (Kinerja Karyawan). Semakin besar nilai R² (mendekati 1) maka ketepatannya dikatakan semakin baik, maka dapat dikatakan kontribusi variabel bebas adalah besar terhadap variabel terikat (Setiawan dan Kusrini, 2010). 
Analisis selanjutnya adalah uji hipotesis yaitu uji koefisien regresi parsial (uji t) dan uji koefisien regresi secara simultan (uji F). Uji t digunakan untuk mengetahui apakah kedisiplinan dan insentif secara parsial berpengaruh secara signifikansi terhadap kinerja karyawan. Uji F digunakan untuk menguji pengaruh dari variabel bebas (kedisiplinan dan intensif) secara keseluruhan terhadap variabel terikat (kinerja karyawan). Uji-uji ini dilakukan pada tingkat signifikansi 0,05 .

Selanjutnya dengan bantuan softwere SPSS versi 22.0 dilakukan analisis regresi linear berganda untuk memperoleh persamaan regresinya, yaitu:

$$
Y=a+b_{1} X_{1}+b_{2} X_{2}+e
$$

\section{HASIL DAN PEMBAHASAN}

Berdasarkan pengolahan data yang telah dilakukan diketahui bahwa data yang telah terkumpul dari kuesioner yang diisi responden semuanya memenuhi uji asumsi klasik. Data yang terkumpul memenuhi asumsi distribusi normal, antara variabel bebas dan variabel terikat berhubungan secara linier, antar variabel bebas tidak terjadi multikolinearitas, dan tidak ada gejala heteroskedastisitas.

Selanjutnya dari pengolahan data yang telah dilakukan dengan bantuan softwere SPSS versi 22 diperoleh nilai koefisien korelasi (R) dan keofisien determinasi ( $\left.\mathrm{R}^{2}\right)$ sebagai berikut:

Tabel 3 Nilai R dan $\mathbf{R}^{2}$ Model Summaryb

\begin{tabular}{|l|c|r|r|c|}
\hline Model & $\mathrm{R}$ & $\begin{array}{c}\mathrm{R} \\
\text { Square }\end{array}$ & Adjusted R Square & $\begin{array}{c}\text { Std. Error of the } \\
\text { Estimate }\end{array}$ \\
\hline 1 & $.954^{\mathrm{a}}$ & .909 & .905 & .78082 \\
\hline
\end{tabular}

A. Predictors: (Constant), Insentif, Kedisiplinan

B. Dependent Variable: Kinerja

Nilai koefisien korelasi (R) sebesar 0,954 menunjukkan ada hubungan yang sangat kuat antara variabel bebas (kedisiplinan dan insentif) dengan variabel terikat (kinerja karyawan). Kemudian dari nilai koefisien determinasi $\left(\mathrm{R}^{2}\right)$ yang besarnya 0,905 dapat diterangkan bahwa variabel kedisiplinan dan variabel insentif dapat menjelaskan variabel kinerja karyawan sebesar 90,5\% sisanya 9,5\% dijelaskan oleh variabel lain yang tidak dibahas dalam penelitian ini.

\section{Tabel 4}

Uji t

\section{Coefficients $^{\mathbf{a}}$}

\begin{tabular}{|c|r|r|c|c|c|}
\hline \multirow{2}{*}{ Model } & \multicolumn{2}{|c|}{$\begin{array}{c}\text { Unstandardized } \\
\text { Coefficients }\end{array}$} & $\begin{array}{c}\text { Standardized } \\
\text { Coefficients }\end{array}$ & & \multirow{2}{*}{ T } \\
\cline { 2 - 6 } & \multicolumn{1}{|c|}{ S } & Std. Error & Beta & \multicolumn{1}{c|}{} \\
\hline \multirow{2}{*}{ (Constant) } & 9.790 & 1.195 & & 8.190 & .000 \\
\hline
\end{tabular}


Pengaruh Kedisiplinan dan Insentif terhadap Kinerja Karyawan Pada PT. Pnm (Permodalan Nasional Madani) Ulamm Cabang Padangsidimpuan Muhammad Isa

\begin{tabular}{|l|l|l|l|r|r|}
\hline $\mathrm{KD}$ & .061 & .032 & .130 & 2.920 & .062 \\
$\mathrm{IF}$ & .597 & .047 & .855 & 12.676 & .000 \\
\hline
\end{tabular}

a. Dependent Variable: KINERJA

Dari uji t yang dilakukan diperoleh bahwa variabel kedisiplinan secara parsial tidak berpengaruh secara signifikansi terhadap kinerja karyawan karena nilai sig.=0,062> 0,05. Sedangkan variabel insentif secara parsial berpengaruh secara signifikan terhadap kinerja karyawan karena sig. $=0,000<0,05$.

\section{Tabel 5 \\ Uji F}

ANOVA ${ }^{\mathbf{a}}$

\begin{tabular}{|ll|r|r|r|r|l|}
\hline \multicolumn{2}{|l|}{ Model } & \multicolumn{1}{|c|}{$\begin{array}{c}\text { Sum of } \\
\text { Squares }\end{array}$} & Df & $\begin{array}{c}\text { Mean } \\
\text { Square }\end{array}$ & F & Sig. \\
\hline 1 & Regression & 256.916 & 2 & 128.458 & 210.696 & $.000^{\mathrm{b}}$ \\
& Residual & 25.607 & 42 & .610 & & \\
& Total & 282.522 & 44 & & & \\
\hline
\end{tabular}

A. Dependent Variable: Kinerja

B. Predictors: (Constant), Insentif, Kedisiplinan

Sedangkan secara simultan dari uji F yang telah dilakukan diperoleh bahwa variabel kedisiplinan dan variabel insentif secara simultan berpengaruh secara signifikan terhadap kinerja karyawan karena sig. $=0,000<0,05$.

Persamaan regresi linear berganda yang diperoleh adalah:

Tabel 6

Regresi linier berganda

Coefficients ${ }^{\mathrm{a}}$

\begin{tabular}{|cl|r|r|r|r|r|}
\hline \multirow{2}{*}{ Model } & \multicolumn{2}{|c|}{$\begin{array}{c}\text { Unstandardized } \\
\text { Coefficients }\end{array}$} & $\begin{array}{c}\text { Standardized } \\
\text { Coefficients }\end{array}$ & & \\
\cline { 3 - 5 } & & \multicolumn{1}{|c|}{ B } & Std. Error & \multicolumn{1}{|c|}{ Beta } & \multicolumn{1}{c|}{ T } & \multicolumn{1}{c|}{ Sig. } \\
\hline & (Constant) & 9.790 & 1.195 & & 8.190 & .000 \\
KD & .061 & .032 & .130 & 2.920 & .062 \\
IF & .597 & .047 & .855 & 12.676 & .000 \\
\hline
\end{tabular}

b. Dependent Variable: KINERJA

$\mathbf{Y}=\mathbf{a}+\mathbf{b}_{1} \mathbf{X}_{\mathbf{1}}+\mathbf{b}_{\mathbf{2}} \mathbf{X}_{2}+\mathbf{e}$

Kinerja $=$ 9,790 + o,o61 Kedisiplinan + o,597 Insentif + e

Penjelasannya adalah sebagai berikut:

Nilai konstanta adalah sebesar 9,790 menunjukkan bahwa apabila kedisiplinan dan insentif nilainya adalah o atau ditiadakan, maka kinerja karyawan nilainya adalah 9,790 satuan.

Koefisien regresi variabel insentif $\left(\mathrm{X}_{2}\right)$ sebesar 0,597 artinya jika variabel kedisiplinan nilainya tetap dan variabel insentif mengalami kenaikan 1 satuan, maka kinerja karyawan 
akan mengalami kenaikan sebesar 0,597 satuan. Artinya terjadi hubungan positif antara variabel insentif dengan variabel kinerja karyawan, semakin tinggi insentif yang diterima maka akan semakin baik kinerja karyawan dalam perusahaan.

Dari hasil penelitian yang diperoleh di atas dapat dikatakan bahwa penelitian ini sesuai dengan teori yang mengatakan bahwa insentif diberikan kepada pekerja untuk mencapai hasil pekerjaan yang lebih baik (Harsono, 1987). Namun untuk variabel kedisiplinan dalam penelitian ini tidak menunjukkan pengaruh yang signifikan. Hal ini mungkin saja terjadi mengingat PT. PNM ULaMM Padangsidimpuan merupakan lembaga keuangan yang kinerjanya sangat terkait dengan pencapaian target masing-masing karyawannya. Dengan kata lain mungkin saja terjadi seorang karyawan yang kesehariannya kurang disiplin di kantor namun memiliki kelebihan dalam praktik pemasaran dan negosiasi di lapangan. Selain variabel kedisiplinan dan insentif yang diteliti dalam penelitian ini masih ada faktor lain yang mempengaruhi kinerja karyawan antara lain: pelatihan, gaya kepemimpinan, motivasi, sistem seleksi karyawan dan sebagainya.

\section{KESIMPULAN}

Dari penelitian ini dapat disimpulkan bahwa variabel kedisiplinan secara parsial tidak berpengaruh secara signifikan terhadap kinerja karyawan di PT. PNM (Permodalan Nasional Madani) ULaMM Padangsidimpuan. Sedangkan variabel insentif secara parsial berpengaruh secara signifikan terhadap kinerja karyawan di PT. PNM (Permodalan Nasional Madani) ULaMM Padangsidimpuan. Oleh karena itu program pemberian insentif ini sebaiknya dilanjutkan di masa yang akan datang karena dipercaya akan bisa meningkatkan kinerja karyawan.

Secara simultan variabel kedisiplinan dan variabel insentif berpengaruh secara signifikan terhadap kinerja karyawan di PT. PNM (Permodalan Nasional Madani) ULaMM Padangsidimpuan. Walaupun sebenarnya di luar variabel kedisiplinan dan variabel insentif masih ada variabel lain yang mempengaruhi kinerja karyawan antara lain: pelatihan, gaya kepemimpinan, motivasi, sistem seleksi karyawan.

\section{DAFTAR PUSTAKA}

Departemen Agama RI, 2010, Al-Qur'an Dan Terjemahan, Jakarta: Jumanatul'ali.

Departemen Pendidikan Nasional, 2005, Kamus Besar Bahasa Indonesia, Jakarta: Balai Pustaka.

Dessler, Gary, 2007, Manajemen Sumber Daya Manusia, Jakarta: PT. Macana Jaya Cemerlang.

Fahmi, Irham, 2012, Manajemen: Teori, Kasus, dan Solusi, Bandung: Alfabeta. 
Fathoni, Abdurrahmat. 2006. Manajemen Sumber Daya Manusia, Jakarta: PT. RinekaCipta Handoko, Hani, T, 1988, Manajement Personalia Dan Sumber Daya Manusia, Yogyakarta: BPFE-Yogyakarta.

Harsono, 1987, Manajemen Publik Cetakan Kedua, Jakarta: Balai Aksara Ghalia Indonesia.

Hasibuan, Malayu SP., 2002, Manajement Sumber Daya Manusia, Jakarta: PT Bumi Aksara.

Nawawi, Hadari, 2011, Manajemen Sumber Daya Manusia Untuk Bisnis Yang Kompetitif, Yogyakarta: Gadjah Mada University Press.

Priyanto, Duwi, 2012, Belajar Cepat Olah Data Statistik dengan SPSS, Yogyakarta: CV Andi Offset.

Rivai, Veithzal, 2004, Manajemen Perusahaan Untuk Perusahaan, Jakarta: PT. Raja Grafindo Persada.

Setiawan dan Kusrini, Endah, Dewi, 2010, Ekonometrika, Yogyakarta : CV, Andi, Offset.

Sugiono dan Susanto, Agus, 2015, “Cara Mudah Belajar SPSS ”, Bandung : Alfabeta.

Suwanto, 2013, Manajemen SDM Dalam Organisasi Publik Dan Bisnis, Bandung: Alfabeta. 